\title{
Novedades de la Corte Suprema de Justicia de la Nación
}

Juan Francisco Díaz

La Corte Suprema consideró que se cumple con la Corte Interamericana al dejar asentada su decisión en una sentencia nacional

El máximo tribunal del país, a través de la Resolución $4015 / 17$, volvió a pronunciarse en una derivación del caso "Fontevechia". La Corte consideró que asentando en la sentencia nacional que aquella fue declarada incompatible con la Convención Americana de Derechos Humanos se cumple con el mandato de la Corte Interamericana de Derechos Humanos. Reafirmó, además que una medida como la sugerida no vulnera los principios de derecho público establecidos en la Constitución Nacional.

La Corte Suprema confirmó la prisión preventiva de Milagros Sala y descartó la posibilidad de que posea inmunidad de arresto

En el primero de los pronunciamientos, por unanimidad, rechazó que Milagro Sala posea inmunidad de arresto como parlamentaria del Mercosur, declarando inconstitucional el artículo 16 de la ley 27.120 en la medida en que asimila a los parlamentarios del Mercosur, que representen a la ciudadanía argentina, a los diputados nacionales en materia de inmunidades parlamentarias. (CSJN "Sala, Milagro Amalia Ángela y otros s/p.s.a. asociación ilicita, fraude a la administración pública y extorsión", 5 de diciembre de 2017)

El segundo pronunciamientos decidió por unanimidad confirmar la prisión preventiva de Milagro Sala. Los jueces Lorenzetti, Highton, Maqueda y Rosatti ordenaron que se cumpla con la sentencia de la Corte Interamericana de Derechos 
Humanos, requirió a las autoridades judiciales a cuya disposición está detenida para que, con urgencia, se cumpla con la decisión dictada por la CIDH que resolvió que debe sustituirse la prisión preventiva por la medida alternativa de arresto domiciliario o por cualquier otra medida menos restrictiva. (CSJN" Sala, Milagro Amalia Ángela y otros s/p.s.a. asociación ilícita, fraude a la administración pública y extorsión”, 5 de diciembre de 2017)

\section{Salta no puede dar educación religiosa en las escuelas públicas}

En coincidencia con lo dictaminado por la Procuración General, en un voto en mayoría, la Corte Suprema de Justicia de la Nación, declaró la inconstitucionalidad de la ley provincial de educación, que incluye la enseñanza religiosa en los planes de estudio, que se imparte dentro de los horarios de clase, por considerar que la enseñanza de un solo culto es discriminatorio y afecta la privacidad de los alumno. El juez Horacio Rosatti en minoría sostuvo que la ley provincial es constitucional toda vez que constituye una elección que expresa el 'margen de apreciación provincial' para implementar la competencia educativa reconocida por el art. 5 de la Constitución Nacional. (CSJN "Castillo, Cárina Viviana y otros c/Provincia de SaltaMinisterio de Educación de la Prov. de Salta s/amparo”, 12 de diciembre de 2017)

\section{La Corte Suprema cerró la causa Papel Prensa}

Así lo hizo el máximo tribunal, con voto de Lorenzetti, Highton, Maqueda y Rosatti, al utilizar la facultad que le da el artículo 280 del Código Procesal para rechazar un recurso sin dar fundamentos. De esta forma concluye la causa por la presunta apropiación ilegal de Papel Prensa al confirmar los sobreseimientos de Héctor Magnetto, CEO del Grupo Clarín, y de Bartolomé Mitre, directivo del diario La Nación. (CSJN "Recurso de hecho deducido por Lidia Elba Papaleo en la causa Magnetto, Héctor y otro s/delito de acción pública", 26 de diciembre de 2017) 
La Corte dejó sin efecto la condena por daños a una persona en un evento gratuito organizado por la Comunidad Homosexual Argentina

El máximo tribunal se apartó de la aplicación de la doctrina del caso "Mosca", entendiendo que no resulta aplicable al presente caso toda vez que la situación del organizador de un espectáculo deportivo que persigue un fin de lucro no puede compararse con la de una asociación civil que realiza una actividad de interés general. El Dr. Maqueda, destacó que no debe dejar de ponderarse que la responsabilidad atribuida a asociaciones como la demandada por su sola condición de organizadora de una actividad a realizarse en un espacio público, podría comprometer el ejercicio de la libertad de expresión y el derecho de reunión consagrados; mientras que el juez Lorenzetti resaltó que en el caso no se trata de una relación de consumo (art. 2 LCD y 1092 CCC), y que si se confirmara la sentencia se reducirían los incentivos para la organización de eventos públicos por parte de entidades sin fines de lucro, lo que también podría predicarse respecto del Estado. (CSJN "Recurso de hecho deducido porla Comunidad Homosexual Argentina en la causa Arregui, Diego Maximiliano c/Estado Nacional-PFA-Y otros s/daños y perjuicios", 26 de diciembre de 2017)

\section{Es discriminatorio el despido por pedir un aumento salarial}

Así lo dispuso la Corte Suprema de Justicia de la Nación, con los votos de los Jueces Highton de Nolasco, Maqueda y Rosatti, al revocar dos fallos del Superior Tribunal de Justicia de Córdoba que habían rechazado reclamos de indemnización especial por despido discriminatorio de dos trabajadores de la cadena de supermercados "Libertad" que fueron despedidos luego de presentar una nota a su empleadora para que evaluara la posibilidad de otorgar un aumento salarial. (CSJN "Recurso de hecho deducido por la parte actora en la causa Farrell, Ricardo Domingo c/Libertad S.A. s/despido", 6 de febrero de 2018) 


\section{La Corte se expidió sobre la estabilidad de los representan- tes sindicales}

La Corte Suprema de Justicia, con voto de los jueces Lorenzetti, Highton, Maqueda y el voto concurrente de Rosatti, sostuvo que los representantes sindicales solo pueden ser privados de estabilidad laboral si el empleador demuestra en forma previa y judicialmente causas válidas de suspensión o despido. La decisión de los magistrados revocó una sentencia que había privado a un docente universitario de la garantía legal de estabilidad en el puesto de trabajo que ampara a los representantes sindicales. (CSJN "Recurso de becho deducido por la demandada en la causa Universidad Nacional de Rosario c/Calarota, Luis Raúl s/exclusión de tutela sindical", 15 de febrero de 2018) 